\title{
RESEARCH OF KARAÇEVA BENTONITE IN NATURAL STATE AND AFTER TREATMENT
}

\author{
Mehush Aliu*, Mensur Kelmendi, Luljeta Pula-Beqiri, Milaim Sadiku \\ and Sadija Kadriu \\ Department of Technology, University of Mitrovica "Isa Boletini", 40000, Mitrovicë, Kosovë \\ "E-mail: mehush.aliu@umib.net
}

\begin{abstract}
The aim of this paper is to research the mineralogical and structural properties of Karaçeva bentonite, as well as to determine that how acid activation changes the structural and mineralogical properties of bentonite. From the obtained results was found that Karaçeva bentonite contains montmorillonite as the main mineral, accompanied by other minerals, such ilit, quartz, feldspar, dollomite and calcite. The natural bentonite fractions with a particle size smaller than $2 \mu \mathrm{m}$ are characterized by increased montmorillonite content and reduction of quartz content. The results of diffractometric and thermogravimetric measurements shows that the Karaçeva bentonite contains very little calcite and dollomite.The diffractometric studies has shown that the basic activation of these bentonites has not resulted in any change in their mineral composition. Acid activation, has changed the structural and mineralogical properties of Karaçeva bentonite.

Keywords: bentonite, acid activation, diffractometric analysis, DTA and TGA analysis
\end{abstract}

(C) RASĀYAN. All rights reserved

\section{INTRODUCTION}

Clays whose basic clay mineral is montmorillonite, or smectite, are generally called bentonites ${ }^{1}$. The physico-chemical properties of bentonites plays a major role in all these applications ${ }^{2}$.

Bentonites are seldom found as monomineralic clays and may contain other clay and non clay minerals and also some organic impurities ${ }^{3}$. Owing to their structural properties, clays are used in many ways including construction, foundry, insulation, adsorption, filter aids, catalysis ${ }^{4}$.

The properties of bentonite clays depends on the structure and chemical composition, exchangeable ion type and small particle size of smectites.

These properties include large specific surface area, high cation exchange capacity, and others physicalchemical properties, such as: swelling, plasticity, cohesion, compressibility, strength, particle size, adsorptive properties, pore structure, surface acidity, and catalytic activity 5 .

As it is well known, the clay minerals are hydrous aluminum silicate and are classified as phyllosilicates. They have a layered structure which can be described as constructed from two modular units: a sheet of corner-linked tetrahedra and a sheet of edge-linked octahedra ${ }^{6}$.

Bentonite clays have the best adsorption properties, into which composition enters montmorillonite. Montmorillonite is capable of essentially increasing initial volume on account of water adsorption in the interlayer sites ${ }^{7}$.

\section{Materials and Methods}

\section{EXPERIMENTAL}

In this paper, the research object was bentonite of Karaçeva source, which is in the eastern part of Kosova. Experimental research of bentonite samples is carried out using these methods: acidic and basic treatment, diffractometric analysis, DTA and TGA analysis.

\section{Acidic and Basic Treatment}

The acid treatment, besides leaching cations from octahedral and tetrahedral sheets, dissolves impurities such as calcite and replaces the exchangeable cations with hydrogen ions ${ }^{8}$. 
Acid activation is carried out with the boiling of bentonite in the sulfuric acid digestion, with concentrations of $10 \%$ and $20 \%$, for 3 hours. Samples are basically activated with a solution of $3 \% \mathrm{Na}_{2} \mathrm{CO}_{3}$.

\section{Diffractometric Analysis}

The diffractometric analysis of the powders with X-ray is the basic technique for clay mineral analysis. This method is used to identify the mineral components of bentonite, such as montmorillonite, feldspar, quartz, calcite, gypsum and zeolites. By means of the difractometric analysis, is determinated the mineralogical composition of the natural sample, the sample with fraction smaller than $2 \mu \mathrm{m}$, the sample activated with $10 \% \mathrm{H}_{2} \mathrm{SO}_{4}$ and with $3 \% \mathrm{Na}_{2} \mathrm{CO}_{3}$.

Differential thermal analysis and Thermogravimetric Analysis

Differential thermal and thermogravimetric analyzes have been used as thermal methods for characterizing the mineralogical composition of the analyzed samples, for quantitative determination of constitutional water, and water contained in the pore and between the layers ${ }^{9}$. With differential thermal and thermogravimetric analysis were investigated the natural sample and activated sample with $3 \% \mathrm{Na}_{2} \mathrm{CO}_{3}$.

Differential thermal analysis curves of smectite are usually divided into three areas:

1. Low-temperature areas $\left(<300^{\circ} \mathrm{C}\right)$,

2. Dehydroxylation zone $(400-750)^{\circ} \mathrm{C}$ and

3. Areas with high temperature $\left(>800^{\circ} \mathrm{C}\right)^{10}$.

\section{RESULTS AND DISCUSSION}

The summarized semi-quantitative representation of the mineralogical analysis for various Karaçeva bentonite samples is given in Table-1.

In figures, 1-4 have presented the diffractograms of Karaçeva bentonite in a natural state, fractionated and activated in the acidic and basic way.

Table-1: Results of the diffractometric analysis.

\begin{tabular}{c|c|c|c|c|c|c}
\hline Sample & M & I & C & Q & D & F \\
\hline Natural sample & ++++ & ++ & + & + & + & + \\
\hline Fraction $\leq 2 \mu \mathrm{m}$ & ++++ & ++ & + & - & - & + \\
\hline $\begin{array}{c}\text { Sample activated with } \\
10 \% \mathrm{H}_{2} \mathrm{SO}_{4}\end{array}$ & ++++ & ++ & - & ++ & + & + \\
\hline $\begin{array}{c}\text { Sample activated with } \\
3 \% \mathrm{Na}_{2} \mathrm{CO}_{3}\end{array}$ & +++ & ++ & - & ++ & + & + \\
\hline
\end{tabular}

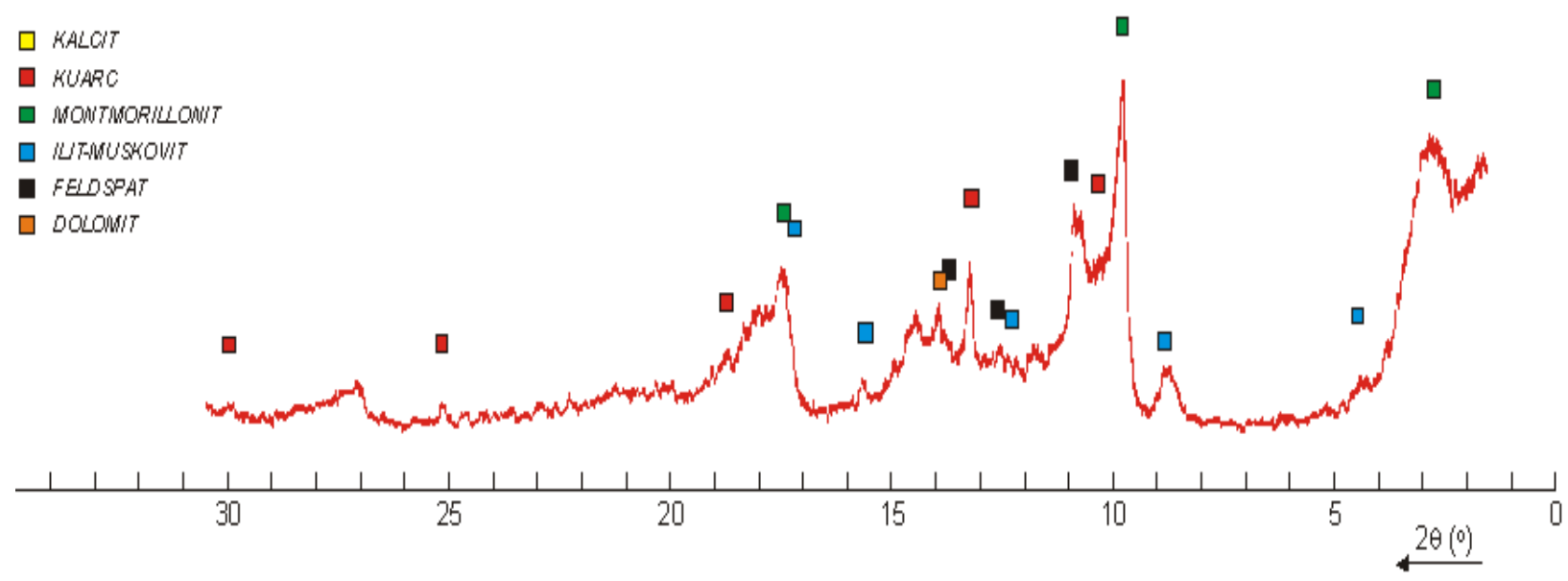

Fig.-1: The diffractogram of a natural sample of Karaçeva bentonite. 
RASĀYAN J. Chem.

Vol. 11 | No. 2 I688 - 693 | April - June | 2018

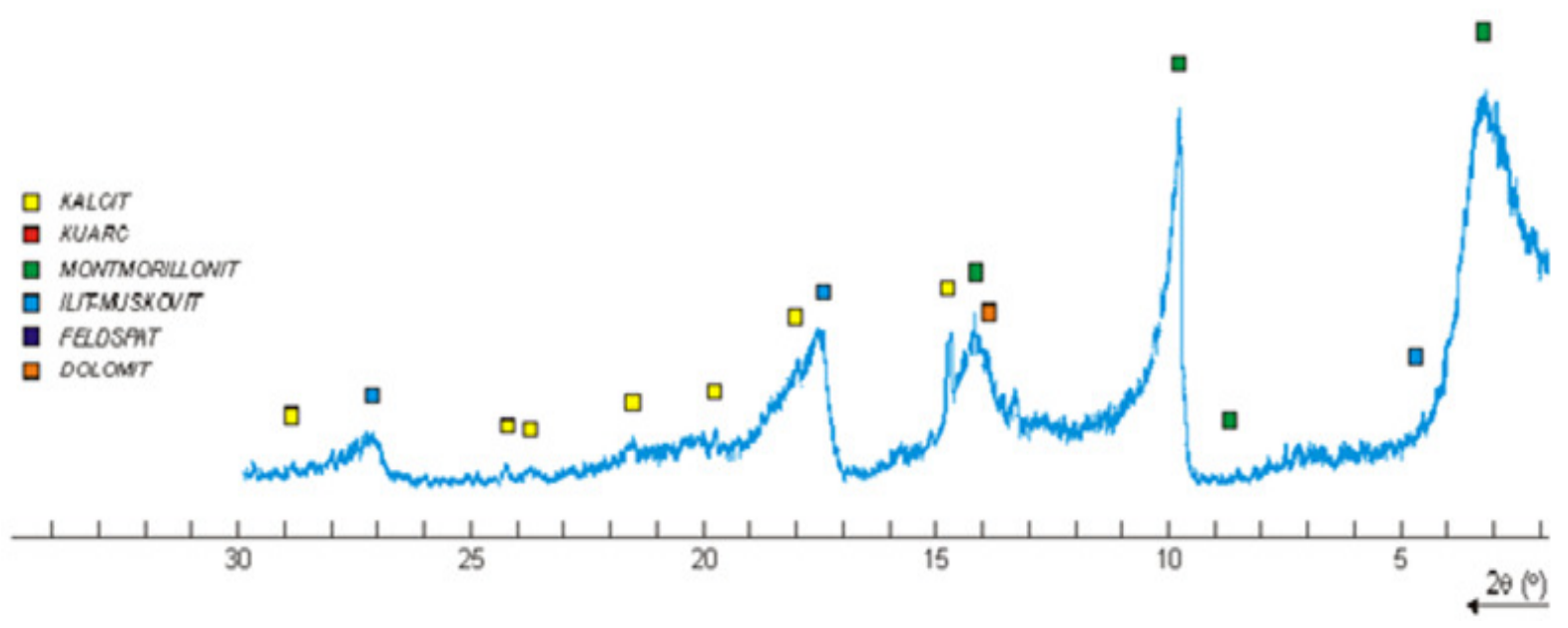

Fig.-2: The diffractogram of Karaçeva bentonite-fraction less $2 \mu \mathrm{m}$.
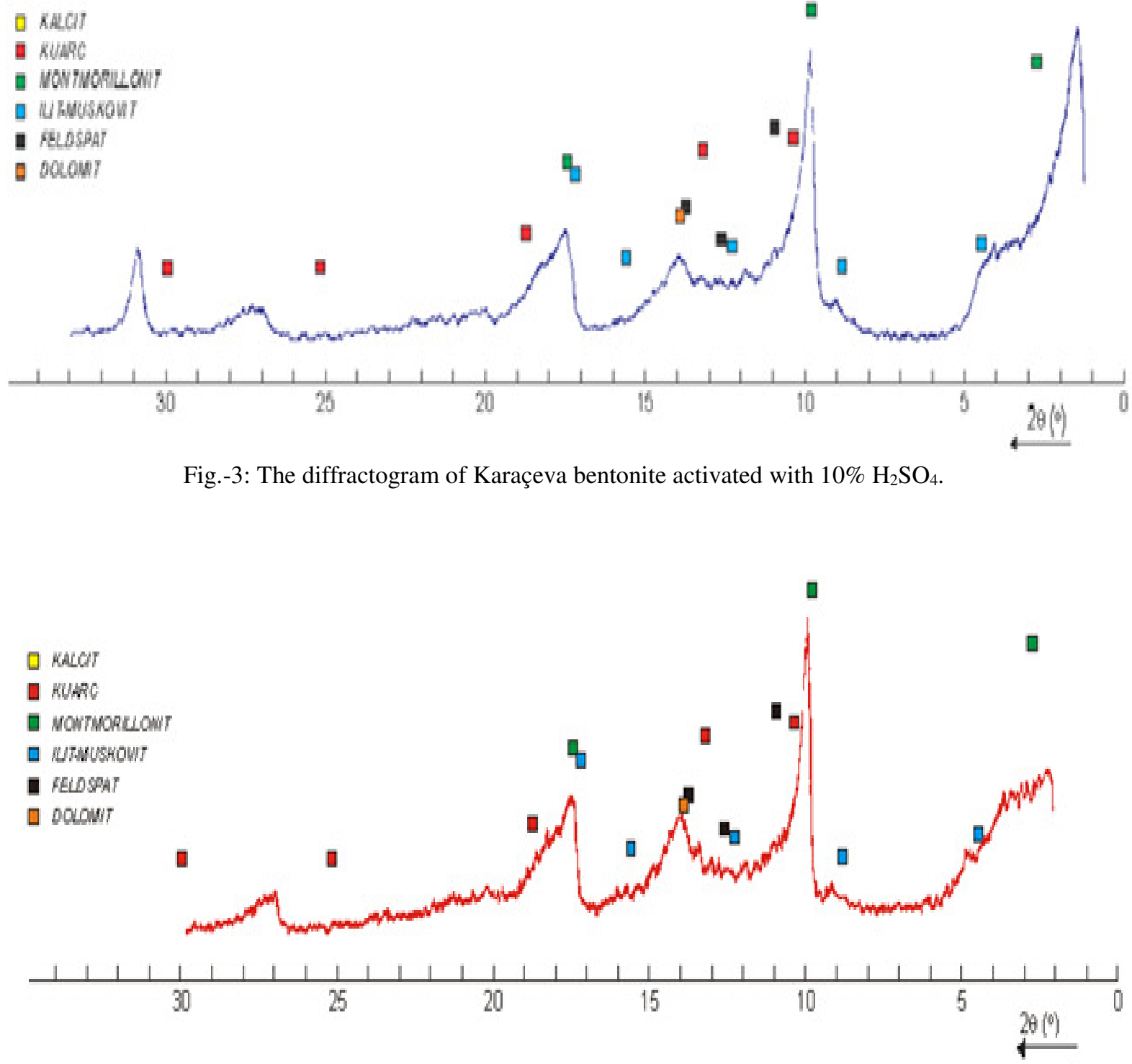

Figure 4. The diffractogram of Karaçeva bentonite activated with $3 \% \mathrm{Na}_{2} \mathrm{CO}_{3}$. 


\section{Results of DTA and TGA analysis}

Figure 5 shows the differential thermal and thermogravimetric analysis of Karaçeva natural bentonite, while in figure 6 are presented the differential thermal and thermogravimetric analysis of bentonite activated with $3 \% \mathrm{Na}_{2} \mathrm{CO}_{3}$. In the Table-2 are presented the results of different parameters of DTA and TGA analysis.

Table-2: Results of DTA and TGA analysis

\begin{tabular}{c|c|c}
\hline Parameters & Natural sample & $\begin{array}{l}\text { Activated sample with } \\
3 \% \mathrm{Na}_{2} \mathrm{CO}_{3}\end{array}$ \\
\hline $\mathrm{t}_{\mathrm{v}}\left({ }^{0} \mathrm{C}\right)$ & 160 & 140 \\
\hline $\mathrm{t}_{\mathrm{q}}\left({ }^{0} \mathrm{C}\right)$ & 580 & 570 \\
\hline $\mathrm{t}_{\mathrm{h}}\left({ }^{0} \mathrm{C}\right)$ & 700 & 700 \\
\hline $\mathrm{t}_{\mathrm{c}}\left({ }^{0} \mathrm{C}\right)$ & 780 & 780 \\
\hline $\mathrm{t}_{\mathrm{r}}\left({ }^{0} \mathrm{C}\right)$ & 870 & 850 \\
\hline $\mathrm{Wv}_{\mathrm{v}}(\%)$ & 8.14 & 7.06 \\
\hline $\mathrm{E}_{\mathrm{h}}(\%)$ & 3.14 & 4.25 \\
\hline
\end{tabular}

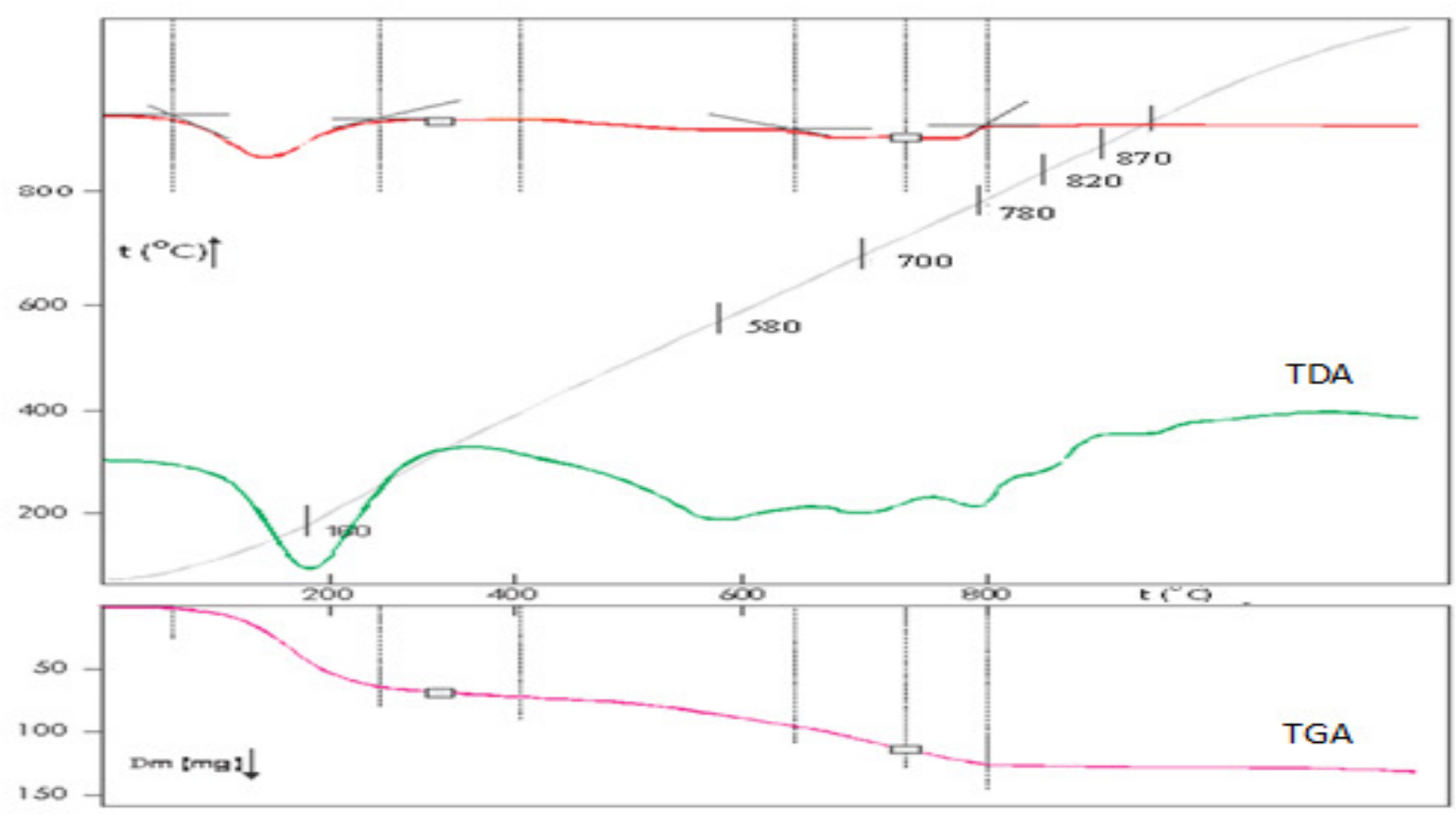

Fig.-5: DTA and TGA analysis of a natural sample

From the diffractometric analysis (Figures-1 to 4 and Table-1), is seen that montmorillonite is the main component of bentonite for all the tested samples, ilite is presented as minor components, while calcite, dollomite, quartz, and feldspar appear as components in the trace.

With the diffractometric analysis of natural bentonites, it has been observed that natural bentonite fractions with a particle size smaller than $2 \mu \mathrm{m}$ are characterized by increased montmorillonite content and reduction of quartz content.

From Fig.-5 and Table-2, for the natural bentonite sample, it is seen that the minimum dehydration temperature is reached at $160^{\circ} \mathrm{C}$, in the low-temperature zone $\left(<300^{\circ} \mathrm{C}\right)$.

The minimum temperature of dehydroxylation and transformation of $\beta$-quartz in $\alpha$-quartz occurs at $580^{\circ} \mathrm{C}$ (dehydroxylation zone $400-750^{\circ} \mathrm{C}$ ), the minimum calcite decomposition temperature is $700^{\circ} \mathrm{C}$, while the 
maximum dehydration temperature is $780^{\circ} \mathrm{C}$. The minimum digestion temperature occurs at $870^{\circ} \mathrm{C}$, water contained in the pore and between the layers is $8.14 \%$, while the constitutive water $3.14 \%$.

From figure 6 and table 2 for the activated bentonite sample, it is seen that the minimum dehydration temperature is reached at $140^{\circ} \mathrm{C}$, in the low-temperature zone $\left(<300^{\circ} \mathrm{C}\right)$, the minimum dehydroxylation temperature and the transformation of $\beta$-quartz in $\alpha$-quartz occur at temperature of $570^{\circ} \mathrm{C}$ (dehydroxylation $400-750^{\circ} \mathrm{C}$ ). The minimum temperature of calcite decomposition is $700{ }^{\circ} \mathrm{C}$, while the maximum dehydration temperature is reached at $780^{\circ} \mathrm{C}$, in the high-temperature zone $\left(>800^{\circ} \mathrm{C}\right)$. The minimum temperature of decomposition occurs at $850^{\circ} \mathrm{C}$, the water contained in the pore and between the layers is $7.06 \%$, while the constitutive water is $4.25 \%$.

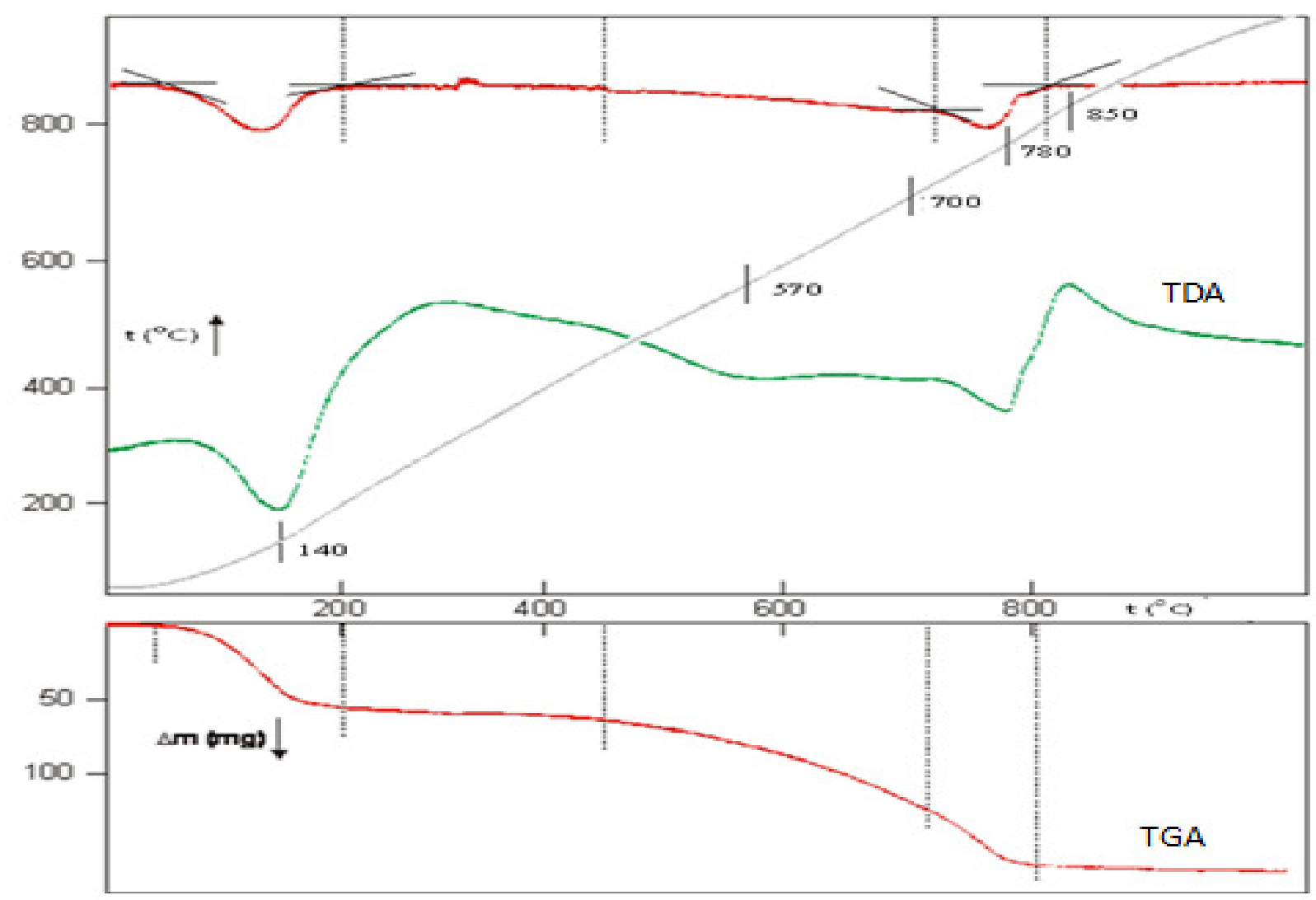

Fig.-6: DTA and TGA analysis of sample activated with $3 \% \mathrm{Na}_{2} \mathrm{CO}_{3}$.

\section{CONCLUSION}

Based on the results obtained from experimental research, can conclude:

- The mineralogical composition of Karaçeva bentonite is characterized by the large presence of montmorillonite in it.

- Acid activation has changed the structural and mineralogical properties of Karaçeva bentonite.

- Acidification of bentonite with $10 \% \mathrm{H}_{2} \mathrm{SO}_{4}$ causes the removal of calcite from bentonite.

- By diffractometric analysis, in the researched samples of natural and activated bentonites, it was found that Karaçeva bentonite contains montmorillonite as the main mineral, accompanied by other minerals, ilit, quartz, feldspar, dollomite and calcite.

- Relevant difractometric studies have shown that the basic activation of these bentonites has not resulted in any change in their mineral composition.

- Based on the results of diffractometric and thermogravimetric measurements, the Karaçeva bentonite contains very little calcite and dollomite. 
RASĀYAN J. Chem.

Vol. 11 | No. 21688 - 693 | April - June | 2018

\section{REFERENCES}

1. M. Onal, Y. Sarikaya, Turk. J. Chem., 26, 409(2002).

2. T. Alemdaroglu, G. Akkus, M. Önal, and Y. Sarikaya, Turk. J. Chem. 27, 675(2003).

3. M. Onal, Commun. Fac. Sci. Univ. Ank. Series B, V52 (2), 7(2006).

4. M. Zubair, International Journal of Emerging Trends in Science and Technology, 2(9), 3126 (2015), DOI: $10.18535 /$ ijetst/v2i9.01

5. C. Oliveira, M. Rocha, A. da Silva, L. Bertolino, Cerâmica, 62, 272(2016), DOI: 10.1590/036669132016623631970

6. N. Stanković, M. Logar, J. Luković, J. Pantić, M. Miljević, B. Babić, A. Radosavljević- Mihajlović, Processing and Application of Ceramics, 5(2), 97(2011).

7. M, Vlasova, G, Dominguez, N, Kakazey, M, Dominguez, D, Juarez, Y, Enriquez, Science of Sintering, 35, 155(2003).

8. F. Valenzuela, P. Diaz, Souza, P. Santos, Quim. Nova, 24, 345(2001).

9. L. Fotic, M. Lausevic, D. Skala, M. Bastic, Instrumentalne metode hemijske analize, Universitet u Beogradu, Tehnolosko-metalurski fakultet, Beograd, (1990).

10. S. Inglethorpe, D. Morgan, D. Highley, and A. Bloodworth, Industrial Minerals Laboratory Manual, BENTONITE, British Geological Survey, Nottingham, (1993).

[RJC-3009/2018] 